\title{
日本雪工学会平成17年度総会報告
}

\section{A General Meeting of Japan Society for Snow Engineering in 2005}

平成 17 年度の日本雪工学会総会は, 平成 17 年 6 月 24 日 (金) 午後 2 時より, 東北大学工学部青葉記念会館 （仙台市荒巻字青葉） 5 階会議室において開催された。開会に先立ち, 石川総務副委員長より会則に基づき 総会が成立していることが報告された。出席者29名, 委任状307通であった。続いて, 吉野会長の挨拶の後, 会則に従い会長が議長となり，以下の次第に沿って議事が進められた。

次第 1 . 総会議題
(1) 平成16年度事業報告
(2) 平成16年度決算報告
(3) 北東北支部の設立について
(4) 平成17年度事業計画
(5) 平成17年度予算
(6) その他

2 . 平成16年度日本雪工学会賞授与

議案 (1)〜(5)については，すべて原案通り可決された。今総会では特に，上信越支部以来の 2 つ目の支部 となる北東北支部の設立が認められ，早速活動を開始することとなつた。

総会議案の審議が終了した後, 平成16年度日本雪工学会賞の選考結果について表彰委員長（表彰規定によ り総務委員長が遂行）より説明があり, 以下の 4 件（4名）に対して学会賞が吉野会長より授与された。出 席した 3 名の受賞者から，それぞれ受賞の挨摱があった。

\section{学 術 賞 千葉大学助教授 高橋 徹氏 \\ 業績名 設計に用いる積雪深の推定手法に関する一連の研究 \\ 学術奖励賞 国士舘大学専任講師 寺内義典氏 \\ 業績名 降積雪時における自動車交通のおくれに関する研究 \\ 北海道立北方建築総合研究所研究職員 堤 拓哉氏 \\ 業績名 陸屋根に形成される雪庇と気象要素との関係に関する研究}

技 術 賞 財団法人 雪だるま財団

業績名「雪冷房でいただきます」〜安塚町立安塚小学校雪冷房の導入について〜

総会終了後, 午後 3 時30分より, 同会場にて雪崩防災委員会の委員長でもある新潟大学積雪地域災害研究 センタ一教授の丸井英明氏により，「中越地震による斜面災害と融雪の影響について」と題して記念講演が おこなわれた。斜面災害の第一人者として中越地震災害調査の陣頭に立ち, 専門的な視点から指導と提言を されてきた丸井先生ならではの内容を, 豊富な現地写真を駆使してわかりやすくお話しいただいた。聴講者 からは被害の実態とメカニズムがよく理解できたとの声が聞かれた。

記念講演のあと, 午後 4 時45分より, 新装なった総合研究棟 1 階のカフェ・デリ・エスパースコマンに場 
所を移し，学会賞受賞者を含め27名の参加を得て懇親会が開かれた。新会場の酒落た䨌囲気と開店サービス が多分に上乗せされた? 会費の割に豪華な料理が大変好評で, 座も盛り上がり，なごやかな中にも熱心に研 究活動や今後の活性化策を語り合う会員の姿がみられた。

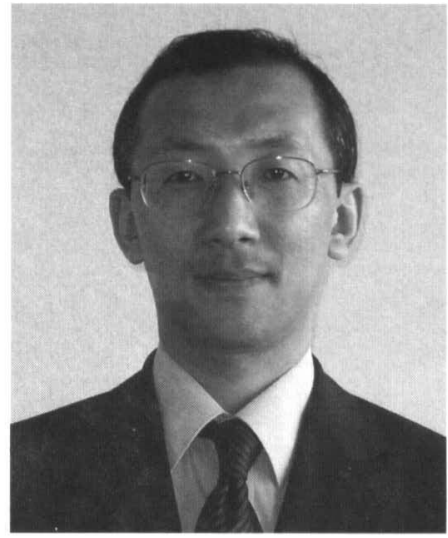

学術賞受賞 高橋 徹 氏

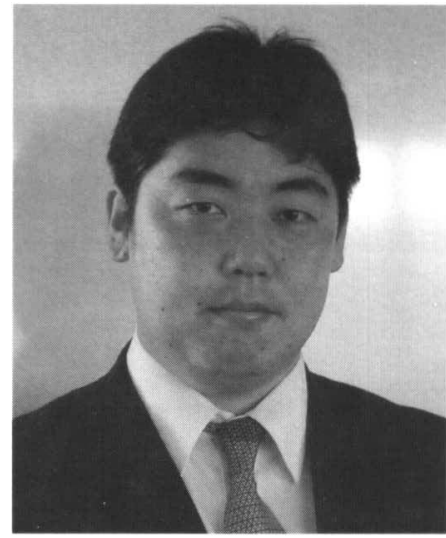

学術奨励賞受賞 寺内義典 氏

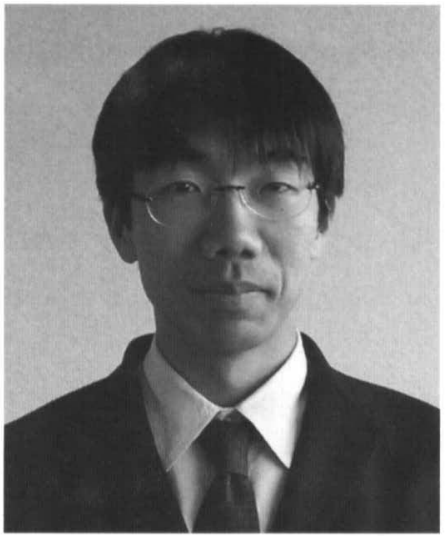

学術奨励賞受賞 堤 拓哉 氏

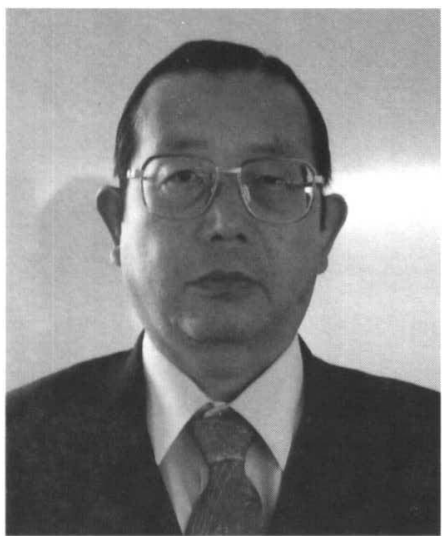

記念講演 丸井英明 氏

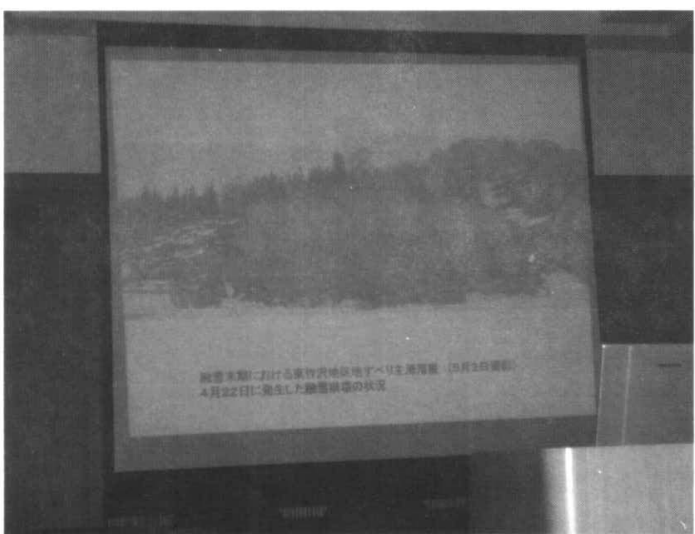

記念講演風景

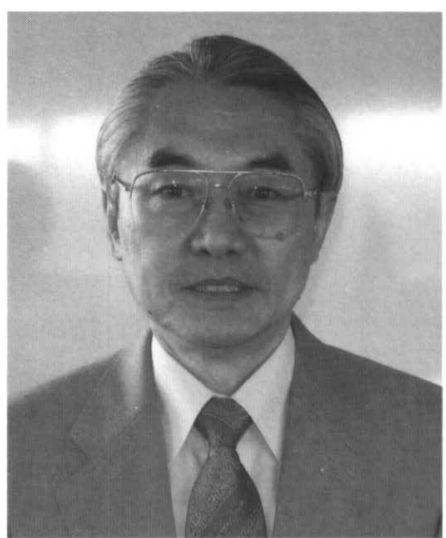

吉野 博 会長

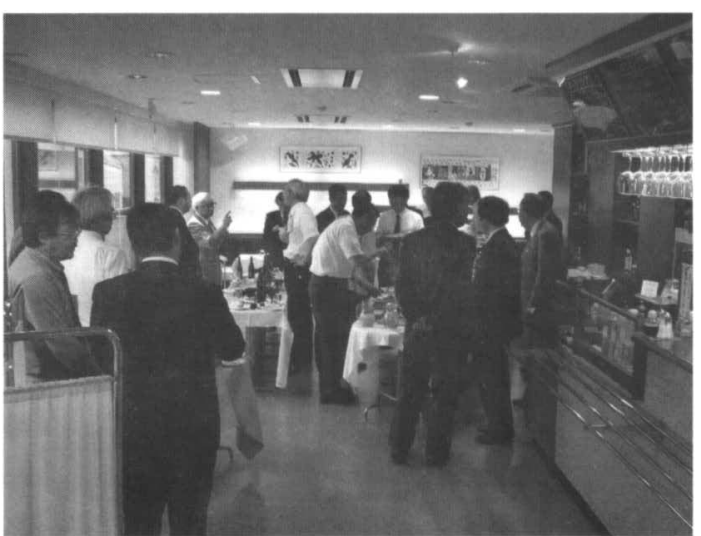

懇親会風景 


\section{平成 16 年度事業報告}

平成16年度は, 学会事業の活性化と組織の充実, 並びに, 雪工学研究の推進と社会への還元を目指して様々 な事業が実施された。しかし，日本学会事務センターの倒産による経理悪化と予算修正，中越地震による年 次大会の縮小など，学会として極めて輹しい状況に置かれた年でもあった。

平成16年度の主な事業は以下の通りである。

\section{(1) 総 会}

平成16年度総会は以下の如く開催された。議案については原案通り承認された。

日 時: 平成 16 年 6 月 25 日

場 所：東北大学工学部青葉記念会館

出席者：30名 (委任状 330 通)

内 容 : 1 . 総会議案審議

(1) 平成 15 年度事業報告

(2) 平成 15 年度決算報告

(3) 平成 16 年度事業計画

(4) 平成 16 年度予算

2. 平成 15 年度日本雪工学会賞授与

3. 総会記念講演

「雪崩対策について」

講師：上石・勲（楋アルゴス雪水技術センター）

\section{（2）臨時総会}

本会がその事務経理業務を委託していた日本学会事務センターが倒産したのに伴い, 臨時総会が開催され, 以下の 2 議案について審議された。その結果, 議案は原案通り承認された。

日 時: 平成 16 年 11 月 15 日

場 所：ハイブ長岡

出席者：30名 (委任状 45 通)

議 案：1．第 1 号議案 会則改定

2. 第 2 号議案 平成 16 年度予算の変更

\section{(3) 理 事 会}

理事会は運営委員会と合同で以下の如く開催され，学会の事業・運営について審議された。

() 理事会の開催

- 第 1 回 平成 16 年 6 月 25 日（於：東北大学 出席者 20 名, 委任状 14 名)

-第 2 回 平成 16 年 9 月 25 日（於：東北大学 出席者 18 名, 委任状 6 名)

・第3 回 平成 16 年 11 月 15 日（於：ハイブ長岡. 出席者 15 名, 委任状 15 名）

- 第 4 回 平成 17 年 3 月 28 日（於：東北大学 出席者 18 名, 委任状 10 名） 
第 2 回理事会は, 日本学会事務センターの破産に伴い学会としての対応策を議論するために，臨時に開 催されたものである。

\section{(4) 運営委員会（委員長・吉野 博）}

理事会と合同で開催し，学会運営の基本方針や具体的活動に関する審議を行った。

\section{（5）総務委員会（委員長・沼野夏生）}

1) 各種内規類の整備

継続して内規類の見直しと整備について意見交換を行った。

2）昨年度作成した雪工学会アクションプラン（仮称）原案にもとづき，他学会特に雪水学会との連 携，支部結成とそのあり方などについて意見交換を行った。

3 ）運営委員会・理事会の開催準備

4 ）事務局業務の遂行

学会事務センターの倒産により，総務委員会気付で暫定事務局を運営することになり，事務センター 問題の事後処理，被害学会同士の連携・情報交換に携わった。また，被害学会対象文科省科研費の申請 に関わる分担作業を行つた。

(9) 委員会の開催

·第 1 回平成 16 年 6 月 9 日（通信）

平成 16 年度雪工学会総務委員会の活動について

（6）編集委員会 (委員長・高橋 弘)

学会誌の編集・発行およびホームページの更新, 管理を行った。

() 委員会の開催

・第 1 回平成 16 年 6 月 4 日（日本道路公団試験所会議室）

- 第 2 回 平成 16 年 8 月 27 日 (東北大学大学院環境科学研究科高橋教授室)

・第3 回 平成 16 年 11 月 23 日〜 24 日 (メールによる通信会議)

- 第 4 回 平成 17 年 2 月 24 日 (東北大学大学院環境科学研究科会議室)

(2) 学会誌の発行 4 回, 5 冊

主な内容:

4 月号 (Vol.20, No.2, Ser.No.71)

論文 2 編

特集「積雪寒泠地における住宅室内環境の現在」

7 月号 (Vol.20, No.3, Ser.No.72)

論文 3 編

特集「平成16年度日本雪工学会総会報告」

特集「道路雪氷を計測するセンサー」

10月号 (Vol.20, No.4, Ser.No.73)

論文 3 編

特集「世界の雪『考』学」 
大会論文特別号（Vol.20，No.5, Ser.No.74）

第21回日本雪工学会大会論文報告集

1 月号 (Vol.21, No.1, Ser.No.75)

速報 中越地震後の雪水災害軽減のために

特集「建築物荷重指針改定」

特集「第21回日本雪工学会長岡大会報告」

\section{（7）組織委員会（委員長・石本敬志）}

委員会運営内規を定め, 会員名簿を整理するなど, 基礎資料を整備した。各分野で様々な角度から, 雪 氷対策の充実に取り組んでいる個人，機関を雪工学会に迎え入れられるよう努力した。しかし，団体，個 人とも, 会員数は減り続けているのが現状で次年度も一層の努力が必要である。また, 委員会運営内規を 定め，学会誌での新入会員紹介など，会員相互の情報交換に努めた。

(O) 委員会の開催

・従来通り，通信による意見交換を行った。

\section{（8）学術委員会（委員長・苫米地 司）}

学術委員会では，以下のことを行った。

1）全国大会発表論文募集

2) 全国大会プログラム編成

3）学会誌論文募集および審査委員選出

4) 番査終了論文の編集委員会へ送付

5) その他

（）委員会の開催

学術委員会は，論文応募などがあった場合に随時開催すると同時に，必要に応じてメール会議を奏施した。

\section{（9）経理委員会（委員長・田中雅順）}

(学会事務センター破産前)

・平成15年度決算報告書の作成，平成16年度予算の立案を行った。

・学会事務センター会計係りと連携して, 各会務委員会および研究委員会等に係る平成16年度会計の出納, 監督業務を行った。

・基金（特別会計）の出納管理を行った。

・会則改定（会費値上げ）について委員会内で検討し，会費值上げ時の仮想予算書を立案した。

・学会事務センター不祥事問題に関する情報収集活動を行った（7月10日の説明会出席）。

(学会事務センター破産後)

・総務委員会と連携し，学会事務センター破産に伴う経理事務業務移管に関わる諸事務作業を行った。

・被害学会刘象文科省科研費の申請に関わる分担作業を行った。

・平成16年度下期臨時修正予算を立案した。

・平成16年度下期会計の出納・監督業務を行った。

・基金（特別会計）の出納管理を行った。 
（）委員会の開催

・第 1 回 平成 16 年 4 月 20 日（通信）

・第 2 回平成 16 年 6 月 16 日 (通信)

·第 3 回 平成 16 年 8 月 20 日（通信）

・第 4 回 平成 16 年 9 月 4 日 (通信)

・第 5 回 平成 16 年 11 月 8 日（通信）

\section{(10) 研究委員会}

\section{- 建物の環境委員会 (委員長・石川善美)}

平成16年度は，積雪寒冷な気候特性に適した住宅設計のためデータベースの充実を図るとともに，各々 の地域にて実測調查等を行いデータベースへ入力するためのデータの取得を行った。

1）当委員会にて蓄積されているデー夕ベースの充実を図るために各地域で調查を行った。主に，実際の 居住状態での室内環境やエネルギー消費量に関する実測調查を行った。

2 ）住宅の居住性や室内環境・エネルギー消費量などについて検討を行い, 積雪寒冷地の住宅の居住環境 に関する現状を把握し，特に，室内環境に関する問題点をまとめた。

$3 ）$ 室内環境に関する問題点として，湿度に関連する建物や居住者の健康への被害が比較的多く見られた ため，国内外の文献をレビューし，同様の問題点がどのようなメカニズムで生じているかを調查した。

() 委員会の開催

·第 1 回 平成 16 年 5 月 25 日（東北工業大学・仙台）

·その他, 通信審議

\section{- 雪冷熱エネルギー利用調查委員会（委員長・和田 惇）}

1）委員会開催

第 1 回委員会開催

日 時 平成16年 9 月 25 日（土） $15: 30 \sim 16: 30$

場 所 東北大学人間環境系大会議室

議 題

・日本雪工学会長岡大会シンポジウム, ポスターセッションについて

・利雪工学ハンドブックについて

・委員会活動の方向性について

2) 日本雪工学会長岡大会パネルディスカッション 新潟県中越地震のため, 中止。

日 時 平成16年11月15日（月）

会 場 ハイブ長岡

テーマ「雪国における雪氷冷熱エネルギーの活用技術と事業化」

3 ）冷熱・利雪ハンドブック作成の検討

雪水冷熱エネルギーの事例集作成に向けて，本学会のホームページを利用して事例を集めることを検討

\section{- 凍上防災委員会（委員長・岡田勝也）}

1) 平成 16 年 11 月 24 日 群馬県建設会館

委員会：委員会活動打合せ他 講習会：「凍上対策に関する講習会」

$2 ）$ 平成 17 年 2 月 12 日 テールアルメ凍上現場追跡調查

通信委員会は随時実施した。 
- 雪崩防災委員会（委員長・丸井英明）

平成16年10月23日に発生した中越地震により発生した斜面災害に関する調査を実施し，以下の講演会等 において調查報告を行った。特に，中越地震に際し雪崩発生予防椢が多数箇所で損傷を受けたため，施設 の被災状沉調査を行うと共に，積雪期における応急措置に関して行政担当部局に対し提言を行った。なお， 調查活動は次年度も継続の予定。

・雪工学会全国大会開催時における緊急報告会

日 時：平成16年11月15日

場 所：長岡市ハイブ長岡

・ル口町の復興に向けての講演会

日 時: 平成17年 2 月26日

場 所：川口町商工会館

- 道路委員会（委員長・村國 誠）
1 ) 委員会開催
0 回

日本雪工学会長岡大会の開催が，2004年11月15日に縮小開催となったことを受けて，当初予定してい た大会開催期間中の委員会の実施が困難となり，やむなく中止とし，E-mail による通信会議とした。

2）事務局会議

平成 16 年 6 月, 10 月（仙台市）

平成 17 年 2 月 （仙台市） その他随時通信会議を実施

3 ) 活動内容

(1) 2004年雪工学会誌講座担当 テーマ: 冬期道路の安全対策と道路防雪

1 月号 講座を始めるにあたり 村國 誠

凍結抑制舗装東海林更二郎

4 月号 道路雪崩対策看

7月号（特集記事のコラボレーション）

道路雪水を計測するセンサー

・本特集をはじめるにあたり＼cjkstart村國 誠

・視程の測定

高田吉治

・積雪計および融雪制御システムの現状 下村忠一

・各種センサーを搭載した視程障害移動観測車の開発とその活用松沢＼cjkstart勝，鈴木武彦

・センサーを用いた雪崩の検知，予知技術上石 勲

・降雪路面監視装置の開発之試験結果背崎，裕野幹雄

10月号 道路吹雪対策加治屋安彦

(2) 長岡大会パネルディスカッションの担当

中越地震の影響により縮小大会となったことからパネルディスカッションは中止となった。

\section{(11) 上信越支部（支部長・宮内信之助）}

1. 支部総会

1) 総会

日 時：平成16年 8 月 6 日（金） $15: 30 \sim 16: 00$

場 所：長岡技術科学大学 総合研究棟 6 階多目的視聴覚室 $\left(\begin{array}{llll}6 & 0 & 2 & \text { 室 }\end{array}\right)$

2 ）第 1 回委員・幹事合同会議

日 時：平成17年 3 月 23 日（水） $10: 00 \sim 12: 00$

場 所：長岡技術科学大学 機械系会議室 
3）全国大会実行委員会

日 時: 平成16年 9 月 10 日（金） $17: 00 \sim 19: 00$

場 所：長岡技術科学大学 機械系会議室

2、第 4 回研究発表会
日 時：平成16年 8 月 6 日（金） $13: 00 \sim 15: 30$
場 所：長岡技術科学大学 総合研究棟 6 階多目的視聴覚室 $\quad\left(\begin{array}{lll}6 & 0 & 2 \\ \text { 室 }\end{array}\right)$
参 加: 約 30 名

3. 第20回雪シンポジウム\&日本雪工学会長岡大会（長岡市と共催）

・新潟県中越地震のため, 全国大会の研究発表会のみポスターセッション形式で開催

・新潟県中越地震緊急報告会を同時開催
日 時：平成16年11月 15 日（月） $10: 00 \sim 16: 00$
場 所：長岡市 ハイブ長岡
参 加：約 100 名

4. その他シンポジウム等

1) 積雪期地震防災シンポジウム
日 時: 平成16年 6 月 15 日
場 所：六日町
参 加：約 130 名

2) 酸性雪 (雨) シンポ'04（新潟大学酸性雪研究会と共催）

日 時: 平成16年11月 6 日

場 所：新潟大学大学院自然科学研究科

参 加: 約 50 名

3 ）住宅地盤の復旧に関する講演会
日 時：平成16年12月23日（木） 13時00分〜16時00分
場 所：長岡市 四郎丸コミュニティセンター
参 加: 約 70 名

4) 川口町の復興に向けての講演会
日 時：平成17年 2 月 26 日（土） 13 時00分～16時30分
場 所：川口町商工会館 二階大研修窒
参 加：約 90 名

5 ) 栃尾市の復興に向けての講演会
日 時：平成17年 3 月 19 日（土） $13: 00 \sim 16: 30$
場 所：杤尾市文化センター 三階大会議室
参 加: 約 70 名

(12) 新潟県中越地震 - 雪水災害調查検討委員会

平成16年10月23日, 新潟県中越地方に発生した, 未だかつて経験したことのない「山村豪雪地域におけ る積雪期前の大規模地震」に対し, 日本雪水学会と合同の委員会を組織して調查活動を実施した。主な活 動内容は以下の通りである。

平成16年11月14日「中越地震後の雪水災害軽減のために（速報）」の取りまとめと公表

平成16年12月 3 日「中越地震後の雪水災害軽減のために」 （住民向けリーフレット）の作成（45,000部）と配布 
平成16年12月〜平成17年 1 月 報道等を通じた啓蒙活動

平成16年12月～平成17年 4 月 継続的（不定期）な現地調査および災害発生時の緊急調查

$$
\text { (ワーキンググループ単位または個人単位) }
$$

平成16年 5 月15日 活動報告会開催・解散

活動内容の詳細は http：//snowy.web.infoseek.co.jp/winter_eq/ 工学会誌 Vol.21 No.1にも中間報告として揭載した。

\section{(13) 平成 16 年度科学研究費（特別研究促進費）への応募亡補助金の獲得}

日本学会事務センターの破産により学会活動に予期せぬ影響があった学会等を対象に, これらの学会が 実施する事業について科学研究費補助金による助成の募集があり, 本会は, (1)学会の集会活動, (2)学術定 期刊行物の発行，に応募した結果，(2)が採択され，補助金 150 万円を獲得した。

\section{(14) 平成 16 年度日本雪工学会賞の選考亡表彰（表彰委員長・沼野夏生）}

学 術賞高橋 徹

業績名：設計に用いる積雪深の推定手法に関する一連の研究

学術奨励賞 寺内 義典

業績名：降積雪時における自動車交通のおくれに関する研究

堤 拓哉

業績名 : 陸屋根に形成される雪庇と気象要素との関係に関する研究

技 術 賞 財団法人 雪だるま財団

業績名：「雪冷房でいただきます、

〜安塚町立安塚小学校雪冷房の導入について〜

(15) 年次大会（第 21 回日本雪工学会長岡大会）

日 時: 平成 16 年 11 月 15 日

会 場 : ハイブ長岡 （長岡市）

内 容: 平成16年10月23日に発生した新潟県中越地震のため，内容を縮小して実施した。

1) 開会式

2) 研究発表会 発表件数約50題 (参加者 約100名)

3 ）新潟県中越地震緊急報告会（参加者 約100名）

4) 日本雪工学会臨時総会

\section{(16) 講演会等}

1）新潟県中越地震緊急報告会

主 催 本会上信越支部新潟県中越地震対策部会

日 時 平成 16 年 11 月 15 日

場 所 ハイブ長岡 (長岡市) 
2）凍上対策に関する講習会
主 催 本会凍上防災委員会
日 時 平成 16 年1 1 月 24 日
会＼cjkstart場 群馬県建設会館

\section{(17) 共催及び後援事業}

○共 催

1）2004年酸性雪 (雨) シンポジウム

日 時 平成 16 年 1 月 6 日

場 所 新潟大学自然科学研究科管理棟大会議室 (新潟市)

参加者 約 50 名

2) 第23回混相流シンポジウム

日 時 平成 16 年 8 月 7 日

場 所 岡山大学

○後援・協賛

1）積雪期における町民のための地震防災講演会)

主 催 六日町, 本会上信越支部，新潟県六日町地域振興局

日 時 平成 16 年 6 月 15 日

参加者 約130名

2 ）雪サミット2004 in 十日町

主 催 雪サミット2004全国明るい雪自治体会議実行委員会

日 時 平成 16 年 7 月 6 日〜 7 日

場 所 新潟県十日町

3）日本混相流学会「年会講演会2004」

日 時 平成 16 年 8 月 5 日 7 日

場 所 岡山大学

4) 平成 16 年度「雪崩防災週間」

主 催 国土交通省, 都道府県

日 時 平成 16 年 12 月 1 日 12 月 7 日

5 ） 2005 ふゆトピア

主 催 2005糸ゆトピア・フェア実行委員会

日 時 平成 17 年 2 月 3 日 5 日

場 所 北海道旭川市

(18) 会員数（平成 17 年 3 月 31 日現在）
·名誉会員
7 名
- 個人会員 442 名 (海外 1 名含む)
- 学生会員 22 . 名
- 団体会員 133 名
・賛助会員 3 名
合計 607 名 


\section{日本雪工学会・北東北支部の設立について}

\section{日本雪工学会・北東北支部規約（案）}

総 則

第 1 条（名称）本支部㹥日本雪工学会北東北支部（Kita-Tohoku Branch of Japan Society for Snow Engineering) と称する。

第 2 条 (事務局) 本支部は，北東北 3 県（青森，岩手，秋田）のいずれかに事務局を置く。

\section{目的及び事業}

第 3 条（目的）本支部は主に日本雪工学会北東北に関する学術，技術の振興と交流をはかることを目的と する。

第 4 条 （事業）本支部は前条の目的達成のため, 一下記の事業を行う。

1. 積雪寒冷環境に関する調查, 研究とその振興

2. 研究発表会, 講演会, 講習会, シンポジウム等の開催

3. 雪工学教育の振興と技術の指導

4. その他, 本支部の目的達成に必要な事業

会 員

第 5 条 本支部の会員は北東北地方在住の日本雪工学会名兴会員, 個人会員, 団体会員, 賛助会員, 学生会 員及び北東北以外で希望する会員とする。

役 員

第 6 条 本支部に次の役員を置く。

支部長 1 名

副支部長 若干名

支部理事 15名以内 うち支部長，副支部長を含む。

支部会計監事 2 名

支部事務局長 1 名

第 7 条 支部長, 支部理事, 支部監事及び支部事務局長は支部総会において支部役員の中から選任する。

第 8 条 副支部長は支部長が支部理事の中から委嘱し，支部長を補佐し必要に応じて支部長を代行する。

第 9 条 支部理事は支部長，副支部長を補佐し，支部理事会の議決に基づいて会務を処理する。

第10条 支部理事会は支部長が招集し，支部長，副支部長，支部理事で構成され，重要な事項を決議する。

第11条 支部会計監事は每年年度末に会計を監査し，これを支部理事会及び支部総会に報告する。

第12条 支部事務局長は支部会員の中から支部事務長を補佐する若干名の事務局員を選任することができる。 また，事務局は支部会員相互の連絡を行う等の事務を司る。

第13条 本支部に顧問を置くことができる。

第14条＼cjkstart顧問は支部会員であることを問わないが，支部理事会の決議を経て支部長がこれを委嘱する。

\section{役員の任期}

第15条 支部長，副支部長の任期は 2 年とし，同一職については 2 期までとする。

第16条 支部理事, 支部会計監事及び支部事務局長の任期は 2 年とし，再任を妨げない。

第17条 役員の任期は支部総会の翌日とし，その終期は翌々年度の支部総会当日とする。

第18条 補欠による役員の任期は，前任者の残任期間とする。

第19条 本支部は原則として毎年 1 回定期総会を開く他，必要に応じ臨時総会を開くことができる。

付 則

1、この規約は平成17年 6 月 24 日より施行する。 


\section{日本雪工学会 \\ 北東北支部理事（案）}

$\begin{array}{lll}\text { 顧問 首藤 伸夫 } & \begin{array}{l}\text { 東北大学工学部名誉教授 } \\ \text { 日本大学大学院総合科学研究科教授 }\end{array} & \text { 水工学 }\end{array}$

青森県

$\begin{array}{llll}\text { 渡邊 } & \text { 正朋 } & \text { 八戸工業大学工学部教授 } & \text { 建築学 } \\ \text { 塩井 } & \text { 幸武 } & \text { 同上 } & \text { 土木工学 } \\ \text { 佐々木幹夫 } & \text { 同上 } & \text { 水工学 } \\ \text { 月舘 } & \text { 敏栄 } & \text { 同上 } & \text { 建築学 } \\ \text { 檜垣 } & \text { 大助 } & \text { 弘前大学農学生命科学部教授 } & \text { 地理学 } \\ \text { 北原 } & \text { 啓司 } & \text { 同上 教育学部教授 } & \text { 都市計画学 }\end{array}$

岩手県

$\begin{array}{llll}\text { 堺 } & \text { 茂樹 } & \text { 岩手大学工学部教授 } & \text { 水工学 } \\ \text { 井良沢道也 } & \text { 同上 農学部助教授 } & \text { 砂防学 } \\ \text { 田代 } & \text { 亨 } & \text { 横河電子機器 (株) 盛岡技術部長 } & \text { 情報工学 }\end{array}$

秋田県

$\begin{array}{llll}\text { 大森三四郎 } & \text { 大森建設 (株) 社長 } & \text { 土木工学 } \\ \text { 佐々木 孝 } & \text { TPS まち創り研究室長 } & \text { 建築学 } \\ \text { 松本 } & \text { 真一 } & \text { 秋田県立大学システム科学技術学部教授 } & \text { 建築環境学 } \\ \text { 石塚 } & \text { 雄雄 } & \text { 東邦技術 (株) 社長 } & \text { 土木工学 } \\ \text { 鷲谷 } & \text { 信雄 } & \text { 明治コンサルタント (株) 東北支店長 } & \text { 地質学 } \\ \text { 伊藤 } & \text { 驍 } & \text { 国立秋田高専名誉教授・秋田大学講師 } & \text { 防災工学 }\end{array}$

事務局：016-0171 秋田県能代市河户川北西山48-1

大森建設 (株) 内

日本雪工学会北東北支部 事務局 石井昭浩 (Tel. 0185-54-3358) 


\section{平成 16 年 度 決 算 書}

I . 一般会計

収入の部

\begin{tabular}{|c|c|c|c|c|}
\hline 収入の部 & & & & (ムは予算隇を示す) \\
\hline 費 & 16年度修正予算 & 16年度決算 & & \\
\hline 会費収 & $1,800,000$ & $\mathbf{3 5 0 , 0 0 0}$ & $\triangle 1,450,000$ & \\
\hline 個人会員会費 & 設定せず & 60,000 & - & 1.0 口分 \\
\hline 学生会買会費 & 設定せず & & - & (as \\
\hline 団体会員会費 & 設定さず & 90,000 & - & 3曰分 \\
\hline 悬时会全 & 炚造已， & $\frac{200,000}{6.000}$ & 6000 & 3 \\
\hline 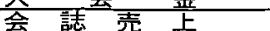 & 30,000 & $9,0,500$ & 64,500 & \\
\hline 論文知刷党上工 & 45,000 & 155,000 & 110,000 & \\
\hline 店告 料 & 0 & 229,160 & 229,160 & 学会誌広华 \\
\hline 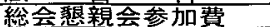 & 40,000 & 48,000 & 8,000 & \\
\hline 20周年記愈事業最入 & $\frac{40,000}{556,500}$ & $\frac{40,000}{159,180}$ & $\mathbf{A} 397,320$ & CD7セット肘売（残り46セット） \\
\hline 利子 - 利 息 & 0 & $\frac{130}{130}$ & 130 & \\
\hline 雜収入 & 0 & 137,037 & 137,037 & 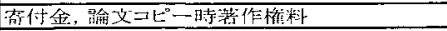 \\
\hline 栱金からの繰入 & 0 & 0 & 0 & \\
\hline 朞金加の借入 & $3,000,000$ & $3,000,000$ & 0 & \\
\hline 転務センター精算金 & 0 & $\frac{0,60,000}{77,690}$ & 77.690 & 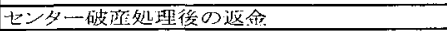 \\
\hline 雏研費 & & $\frac{1,030}{1.500,000}$ & $1,500,000$ & 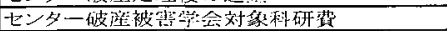 \\
\hline 当年度収入合計 & $5,471,500$ & $\frac{1,50,0097}{5,756,697}$ & 285,197 & \\
\hline 前年度繰越品金 & 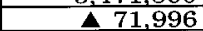 & 279,633 & 351,629 & 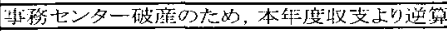 \\
\hline 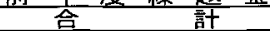 & $5,399,504$ & $6,036,330$ & 636,826 & \\
\hline
\end{tabular}

支出 部

至平成17年3月31日(单位:円)

(Aは予算減交す)

自平成16年4月1日

\begin{tabular}{|c|c|c|c|c|}
\hline 200 慈 & & & & 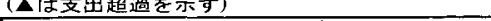 \\
\hline 書 & 16年度修正予算 & 16年度決算 & 増 減 & \begin{tabular}{|c|} 
備 \\
\end{tabular} \\
\hline 事務賈 (暫定事務局) & 0 & 166,545 & $\Delta 166,545$ & 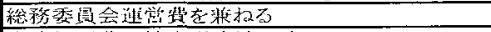 \\
\hline 破産問題処理経費 & 設定ぜず & 41.289 & - & 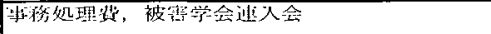 \\
\hline 消 耗 品 & 腷炡せず & 1.887 & - & \\
\hline 印刷費 & 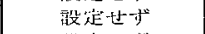 & 2,900 & - & $=ヒ^{0}$ 一代 \\
\hline 通 信 費 & 教往せず & 50,469 & - & 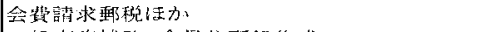 \\
\hline 人 件 畵 & 毁定せず & 70,000 & - & 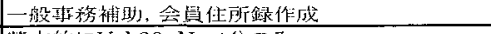 \\
\hline 会 誌 & $2,195,500$ & $2,439,525$ & $\triangle 244,025$ & 些本的にVol.20, No.4分のみ \\
\hline 編 集 費 & 60,000 & 30,000 & 30.000 & Vol.20, No.4素で \\
\hline 印刷貫 & $1,960,000$ & $2,403,525$ & $\Delta 443.525$ & Vol, 20, No. 3, No. 4, 大会号 \\
\hline 発 送費 & 137,500 & & 137,500 & No.4分未处理 \\
\hline 論文査読料 & 6,000 & 6,000 & & \\
\hline 論文校正料 & 12,000 & 0 & 12,000 & \\
\hline 原 稿 料 & 20,000 & 0 & 20,000 & \\
\hline 年次大会開催費 & 0 & 0 & 0 & 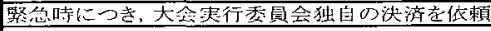 \\
\hline 会務委員会 & $1,005,000$ & 554,828 & 450,172 & \\
\hline 総 & 100,000 & 25.866 & 74,134 & 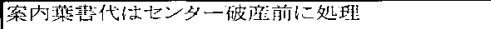 \\
\hline 総会㯏親会 & 40.000 & 50,000 & $\Delta 10,000$ & \\
\hline 理 事 会 & & 25,617 & - 25,617 & 全議歰 \\
\hline 運赏委員会 & 50,000 & 34,675 & 15,325 & センター破彦問題処理のため \\
\hline 総務委員会 & 300,000 & - & & 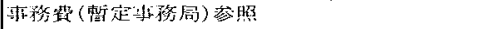 \\
\hline 編集委員会 & 450.000 & 397,635 & 52,365 & \\
\hline 組織委畣会 & & & & \\
\hline 学術委員会 & 50.000 & 18.830 & 31,170 & \\
\hline 経理委員会 & 15,000 & 2,205 & 12,795 & \\
\hline 委員会 & 0 & 53,130 & $\Delta 53,130$ & 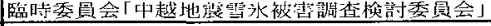 \\
\hline 学会賞選考委員会 & 0 & 0 & 0 & \\
\hline 基 金 繰 & 0 & 0 & 0 & 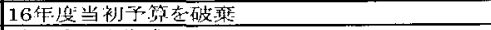 \\
\hline 会勢拡大費 & 50,000 & 49,350 & 650 & パンプレット作成 \\
\hline 特 別事 業 雷 & $\mathbf{0}$ & 0 & 0 & \\
\hline 会員名涳制作費 & 0 & 0 & 0 & \\
\hline 学会賞賞牌制作費 & $\mathbf{0}$ & 0 & 0 & \\
\hline 20周年記念事業費 & 74,200 & 45,675 & 28,525 & 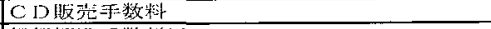 \\
\hline 雜 蒦 & 30,000 & 7,148 & 22,852 & 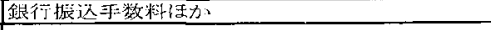 \\
\hline 予 備 貫 & $1,544,804$ & 0 & $1,544,804$ & \\
\hline 基金借入金返済 & 500,000 & 0 & 500,000 & 16 作度抹執行 \\
\hline 当年度支出合計 & $5,399,504$ & $3,316,201$ & $2,083,303$ & \\
\hline 次年 度繰 越 金 & 0 & $2,720,129$ & $\Delta 2,720,129$ & \\
\hline 合 & $5,399,504$ & $6,036,330$ & $\triangle 636.826$ & \\
\hline
\end{tabular}

\begin{tabular}{|c|c|c|c|}
\hline 賚 & 16年度臨時修正 & 16年度決算 & 備 \\
\hline 前年度繰越金 & $7,217,457$ & $7,217,457$ & \\
\hline 一般会計への繰出 & 0 & 0 & 支出, \\
\hline 二般会計からの繰入 & 0 & 0 & 破躷 \\
\hline 一般会計への買出 & $-\overline{3}, 000,000$ & $-3,000,000$ & \\
\hline 二般会計からの返済 & 500,000 & 0 & \\
\hline 利 息 & 65 & 65 & 定昫解約手数料之の美額 \\
\hline 合 & $4,717,522$ & 4.217 .522 & 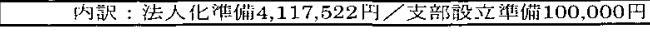 \\
\hline
\end{tabular}

\section{会 計 監 査 報 告 書}

会計監查の結果, 平成16年度決算書の内容に相違ないことを報告します。

平成 17 年 6 月 24 日

日本雪工学会・会計監事 三渏安則・寺田章次 


\section{平成 17 年度事業計画}

\section{【運営方針】}

従来の多くの雪害を教訓とした雪害対策と雪国の快適な生活環境づくり，とくに高齢者人口の增加や産業 構造の変化等に対応した地域づくり, 雪の利用と地域振興に関する調査・研究と技術開発の一層の推進を図 り，社会に貢献する。

\section{(1) 総会}

日 時: 平成 17 年 6 月 24 日 $14: 00 \sim 16: 30$ （学会賞授与式，記念講演会を含む）

場 所 : 東北大学工学部青葉記念会館

\section{(2) 理事会}

・理事会の開催 3 回（通信理事会は随時）

\section{（3）運営・会務委員会}

我国唯一の雪工学に関する学術研究団体としての特色を持った事業活動の推進を図るべく運営を企画し, また，会員の増加と組織の充奏を図る。主な事業計画は以下の如くである。

1）学会誌の内容の充実, 特に論文・技術報告・各委員会報告等の揭載数の増加と情報の収集等を通して 会員の参加・交流を図る。また，そのためのホームページの一層の充実を図る。

2 ) 法人化の必要条件に関する個人会員の增加と学会財政基盤の整備, 研究活動の推進を図るための重点 事業を企画し，成果の社会への還元を図る。

3 ）各会務委員会事業の推進

\section{（）各委員会の開催予定（通信会議を含む）}

- 運営委員会 3 回

·総務委員会 3 回

・編集委員会4回

・組織委員会 3 回

- 学術委員会 2 回

・経理委員会 2 回

会務委員会の具体的な事業計画は以下の通りである。

\section{○総務委員会}

1) 各種内規類の整備

2) 雪工学会アクションプランの検討

3 ）各地域のニーズの調査と各種イベントの企画提案

4 ) 運営委員会・理事会の開催準備等

5 ）事務局業務の遂行と新事務局体制の確立. 
1) 学会誌の編集・発行 4 回

2) ホームページの更新メンテナンス

\section{組織委員会}

団体, 個人とも, 会員数は減り続けているのが現状で一層の努力が必要である。日々, 委員が率先して 努力することとして,

・未加入団体, 個人への働きかけ強化

・異動に伴う連絡先変更の徹底

・会費末納, 滞納会員への働きかけ強化

・整備した会員名簿を活用するなどして，月に一度程度，組織委員が組織強化のために努力し，年表 にまとめる。

など, 努力すると共に, 関係機関との連携に努める。加えて, 昨年度に引き続き, 学会誌での新入会員 紹介など，会員相互の情報交換に務める。

\section{学術委員会}

学術委員会では，以下の活動を行う。

1）全国大会発表論文募集

2）全国大会プログラム編成

3 ）学会誌論文募集および審査委員選出

4) 審查終了論文の編集委員への送付

5) その他

委員会は，論文応募などがあった場合に随時開催すると同時に，必要に応じてメール会議を実施する予 定である。

\section{経理委員会}

経理委員会では，以下の定常的な経理業務を行う。

1) 平成 16 年度決算報告書の作成

2) 平成 17 年度予算の立案

3 ）各会務委員会および研究委員会等に係る平成16年度会計の出納及び監督

4 ）基金（特別会計）の管理

また, 総務委員会, 編集委員会と連携して以下の業務を行う。

1 ）会費納入状況の掌握

2）会誌発刊関係の経理（印刷費の支出，別刷代金の請求亡入金確認）

さらに，収支悪化抑制策として，理事会・総会に以下の件の提案を計画する。

1）会則（会費）の改正 


\section{(4) 研究委員会}

\section{《プロジェクト型委員会》}

\section{- 建物の環境委員会（委員長・石川善美）}

積雪寒冷地という気候特性に適した住宅の環境設計のためのデータベース整備を進める。本年度は，(1) これまでと同様にデータの充実を図るために，実際の居住状態での室内環境やエネルギー消費量に関する 実測調查を行うと共に，(2)データベースの活用方法について更に検討を重ね，良質な住宅設計のための有 カなツールとすべくデータベースシステムの構築を行う。さらに, (3)本委員会にて得られた成果をもとに 公開シンポジウムを開催し，積雪寒冷地の住宅環境への関心を高めるよう啓発する。

以上の作業を通して, 積雪寒冷地における建物シェルター性能の役割と課題, 暖房, 換気など建築設備 の技術的課題について，雪国特有の環境工学的研究手法について検討する。

\section{- 雪冷熱エネルギー利用調査研究委員会（委員長・和田 惇）}

1）委員会開催開催予定 2 回

2) 雪水冷熱シンポジウムの開催

雪水冷熱エネルギーの技術開発に擭わってきた開発者や研究者, 行政担当者等を迎え, シンポジウム を開催する。

3）冷熱・利雪ハンドブックの作成

冷熱・利雪ハンドブックの作成に向けて，日本全国から事例を $\mathrm{HP}$ 等を利用して，収集する。

4 ）中山間地域の集雪技術に関する研究

中山間地域における山峡，斜面を利用した効率的な集雪，輸送技術の研究を行う。

\section{《情報交換型委員会》}

\section{- 凍上防災委員会 (委員長・岡田勝也)}
1）委員会開催
開催予定約 3 回
2）「凍上対策に関する講習会」の開催
3 ）「凍上関係の講演会」の開催
時期・講師未定

\section{- 雪崩防災委員会 (委員長・丸井英明)}

1) 中越地震により発生した斜面災害に関する調査を継続する。特に, 融雪による不安定斜面の変化につ いて評価を行う。

2）小千谷市において開催される復興に向けたシンポジウムにおいて調査報告を行う。

3）秋に開催される雪シンポジウムにおいて, 中越地震による斜面災害をテーマとしてセッションを準備 する。 日時：平成17年11月17日 場所：魚沼市小出

\section{- 道路研究委員会（委員長・村國 誠)}

1) 委員会開催 2 回予定（日時・場所は未定）

2）事務局会議随時開催

3 ） 2005年雪工学会誌講座担当

$$
\text { テーマ：「凍結路面とその対策」 }
$$

4 月号 路面凍結現象とその評価

7 月号 凍結防止剂・液の散布と効用メカニズム

10月号 凍結路面対策

1 月号 凍結予測

合計12名の方に原稿の執筆を依頼する予定 
4) SRニュース発行随時

5) 旭川大会パネルディスカッションの担当

テーマ：「凍結路面とその対策」 詳細は未定

（5）上信越支部（支部長 宮内信之助）

1 ) 支部総会, 第 5 回研究発表会

日 時: 平成 17 年 8 月 5 日（金）

場 所: 長岡技術科学大学 機械系会議室

2) 委員, 幹事合同会議 2 回

場所, 日時未定

3) 酸性雪 (雨) シンポジウム

11 月頃新潟大学工学部

4）地震防災シンポジウム

5) 他

（6）北東北支部（支部長 伊藤 驍）

1) 設立記念シンポジウム（日本雪承学会東北支部と共催）

日 時：平成 17 年 7 月 7 日 (木)

場 所：弘前大学 50 周年記念館

内 容: 平成 17 年青森県豪雪災害シンポジウム

2）理事会開催 場所, 日時未定

3 ) 平成 18 年度日本雪工学会秋田大会開催の検討

(7) 平成 17 年度日本雪工学会賞の選考亡表彰

（8）年次大会（第 22 回大会）

日本雪水学会と合同で，平成 17 年 9 月 26 日〜 30 日の「(仮称) 雪水研究週間」に参加し，その中 で年次大会を開催する。

日 時 平成 17 年 9 月 26 日 27 日

9 月 28 日に, 日本雪水学会と共催でシンポジウムを行う。

場 所 旭川クリスタルホール (北海道旭川市)

(9) 学会誌等の発行

1) 学会誌
4 月号 (Vol.21, No.2, Ser.No.76)
特集「豪雪速報」
7 月号 (Vol.21, No.3, Ser.No.77)
特集「雪崩対策の新技術」
特集「平成16年度日本雪工学会総会報告」
大会諭文特別号（Vol.21，No.4, Ser.No.78）
第22回日本雪工学会大会論文報告集
10月号 (Vol.21, No.5, Ser.No.79)
特集「雪水学会とのコラボレーション」
1 月号 (Vol.22, No.1, Ser.No.80)
特集「第21回日本雪工学会大会報告」
特集「環境科学の視点から見た雪工学」

2) その他

(10) 特別事業

・講演会等の主催, 共催（日時, 場所, 内容については検討中） 


\section{平成 17 年度予算(案)}

I . 一般会計

収入の部
自平成17年4月 1 日

至平成18年3月31日 (単位:円)

(ムは矛算減を示す)

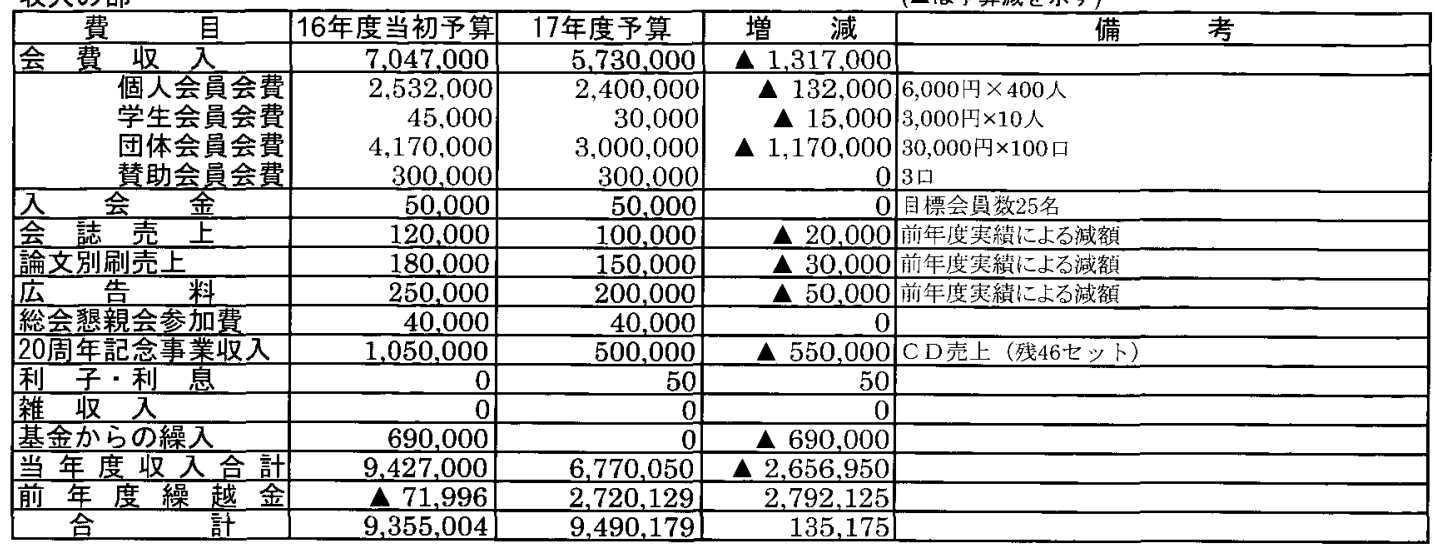

\section{支出の部}

$9,490,179$

(ムは予算隇を示す)

\begin{tabular}{|c|c|c|c|c|}
\hline 費 & 16年度当初予算 & 17年度予算 & 増 & 備 \\
\hline 事務費 (暫定事務局) & $1,610,000$ & 180,000 & $\Delta 1,430,000$ & 総務委員会運営費を兼衫㞋 \\
\hline 破産問題処理経費 & - & 50,000 & & 被害学会連会合旅費など \\
\hline 消 耗 品 & 一 & 5,000 & & \\
\hline 印 刷 費 & - & 3,000 & & \\
\hline 通 信 & - & 50,000 & & \\
\hline 人 件 & - & 72,000 & & アルバイト12人日 \\
\hline 学 & 4.920 .000 & $4,500,000$ & 4420,000 & \\
\hline 編 集 費 & 80,000 & 50.000 & $\Delta 30.000$ & 学会誌Vol.21 No.1 4, 大会号の 5 回分 \\
\hline 印 刷 費 & $4,200,000$ & $4,000,000$ & $\Delta 200,000$ & 学会誌Vol.21 No.1 4, 大会号及び別刷 \\
\hline 発 送 費 & 550,000 & 360,000 & $\Delta 190,000$ & \\
\hline 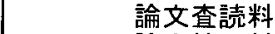 & & & & 查誌料の溌此 \\
\hline 論文校正料 & 50,000 & 50,000 & 0 & 英文校正费用 \\
\hline 原 稿 料 & 40,000 & 40,000 & 0 & \\
\hline 年次大会開催實 & 500,000 & 500,000 & 0 & \\
\hline 会務委員会 & $1,005,000$ & 841,000 & $\Delta 164,000$ & \\
\hline $\begin{array}{ll}\text { 総 会 } \\
\end{array}$ & 100,000 & 100,000 & 0 & 総会葉書, 同印刷費を含导 \\
\hline 総会賏親会 & 40,000 & 40,000 & 0 & \\
\hline 理 事 会 & 180,000 & 0 & $\Delta .180,000$ & 自肃 \\
\hline 運営委員会 & 20,000 & 0 & $\Delta 20,000$ & 自肃 \\
\hline 総務委員会 & 10,000 & & $\Delta 10.000$ & 事務費(暫定事務局)を兼初る \\
\hline 編集委員会 & 600,000 & 600,000 & 0 & \\
\hline 組織委員会 & & & & 会勢搪大蛽老使用 \\
\hline 学術委員会 & 50,000 & 50,000 & 0 & \\
\hline 経理委員会 & 5,000 & 51.000 & 46.000 & Webバンキング使朋料 \\
\hline 研究委員会 & 200.000 & 200,000 & 0 & \\
\hline 支部活 動 費 & - & 100,000 & & 2 支部分 \\
\hline 学会賞選考委員会 & 0 & 0 & 0 & \\
\hline 基 金 繰 入 & 100,000 & 0 & 100,000 & 支部設主準備基金から \\
\hline 会勢拡大費 & 50,000 & 50,000 & 0 & 增収対策 \\
\hline 特別事 業賈 & 50,000 & 100,000 & 50,000 & 沜ポジウム・男版，其催費など2支部分 \\
\hline 会貣名薄制作費 & 0 & 0 & 0 & \\
\hline 学会賞賞牌制作費 & 0 & 0 & 0 & \\
\hline 20周年記念事業賽 & 455,000 & 0 & $\Delta 455,000$ & . \\
\hline 雑 費 & 30,000 & 30,000 & 0 & 送金手数料など，前年度实績に基づく滅額 \\
\hline 茅備 費 & 435,004 & $1,489,179$ & 1.054 .175 & \\
\hline 基金借入金返済 & - & $1,500,000$ & & 16年度未執行分を含む \\
\hline 合計 & $9,355,004$ & $9,490,179$ & $135,1 \overline{75}$ & \\
\hline
\end{tabular}

\section{II. 基金積立（特別会計）}

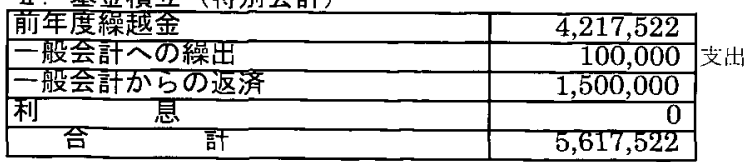

